Case for Teaching

\title{
Stay at Home, Casa Porto Delivers: Humanized Entrepreneurship during Pandemic
}

\section{Fique em Casa, a Casa Porto Entrega: Empreendedorismo Humanizado na} Pandemia

\section{INTRODUCTION}

On April 8, 2020, the first updated bulletin on the coronavirus, released by the State Department of Health of Rio de Janeiro, reported that the state had accumulated 1,688 confirmed cases of COVID-19 and 92 deaths $^{1}$.

While helping organize home deliveries of Casa Porto meals, Raphael Vidal quickly commented on these numbers with some members of his kitchen and lounge staff. They had joined the application delivery system on March 18, 2020.

After the day's activities, he had his last beer that afternoon with the staff and went home. On foot, after all, since 2008 he lived very close, at Morro da Conceição.

1. Universidade Federal do Rio de Janeiro, Instituto COPPEAD de Administração, Rio de Janeiro, RJ, Brazil. 2. Universidade Federal do Estado do Rio de Janeiro, Departamento de Estratégia de Gestão, Rio de Janeiro, RJ, Brazil.

Cite as: Vinhas, V. Q., \& Lopes, A. L. S. V. (2021). Stay at home, Casa Porto delivers: Humanized entrepreneurship during pandemic. Revista de Administração Contemporânea, 25(spe), e200253. https://doi.org/10.1590/1982-7849rac2021200253.en
Reflective, Raphael was concerned about the situation of Casa Porto. That week would be the last one the Inverted Rain Check would be active. This was a project designed by him to help with the revenues of Casa Porto based on the advance of payments by customers, to enjoy the purchases as soon as the pandemic was over. The slogan was "Inverted Rain Check. Our time to count on you." The advance payment strategy also included the sale of tickets for future events of Casa Porto, such as the Bubble Fantasy Party scheduled for October 31, 2020, when Raphael imagined that the pandemic situation would already be circumvented.

EL Code: A20, O15, L66

Editor-in-chief: Wesley Mendes-Da-Silva (Fundação Getulio Vargas, EAESP, Brazil) 둥 Associate Editor: Paula C. P. de S. Chimenti (Universidade Federal do Rio de Janeiro, COPPEAD, Brazil) Guest Editor: Leonardo Marques (Universidade Federal do Rio de Janeiro, COPPEAD, Brazil) (1) Reviewers: Mariana Euflausino (Universidade Estadual de Maringá, DAD, Brazil) (C) Cristiane Gontijo Araújo (Universidade Federal de Minas Gerais, Brazil) Peer Review Report: The disclosure of the Peer Review Report was not authorized by its reviewers. Accepted: December 15, 2020

\begin{tabular}{|c|c|c|c|c|c|c|c|c|c|}
\hline & 1 & 2 & 3 & 4 & 5 & 6 & 7 & 8 & 9 \\
\hline $1^{\text {st }}$ round & & p & & & & & & & \\
\hline $2^{\text {nd }}$ round & 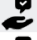 & & & & & & & & \\
\hline $3^{\text {rd }}$ round & & & & & & & & & \\
\hline
\end{tabular}


On March 14, 2020, Raphael made the decision to deploy a distribution channel based on home deliveries by applications such as iFood and Uber Eats, in addition to the use of independent deliverymen only for neighborhoods not served by the applications. The service had never been offered by Casa Porto, which until then operated only with local service. Once the pandemic crisis was confirmed, numerous establishments felt the need to design alternatives to meet the imperative of "closing doors."

The following day, the name of Casa Porto was added to that of other traditional bars and restaurants list in an article published by the newspaper $O G l o b o^{2}$, entitled "Coronavírus: Bars of Rio reinvent themselves to not close their doors and please customers," which recorded: "Casa Porto, in Largo da Prainha, will offer a dose of beat, pepper, and dessert on account of the house for those who order delivery. - In addition to our dishes, we will deliver food of first necessity. If the customer wants a bit of rice, there is. Just beans, there is. Mashed? We have. We will attend everyone" - explains Raphael Vidal.

After using the delivery applications for a couple of weeks, Raphael already resented the high percentage that he paid on top of the sales value, which impacted on his monthly billing and, consequently, on his intention to keep the business running and, mainly, the salary of his team of professionals. In addition, when he reflected about the precarious work conditions to which application delivery workers were subjected to, including strenuous working hours, fall pay, and lack of adequate protection and security, his discomfort increased.

Facing so many uncertainties, difficulties, and concerns, Raphael wondered how he could keep his business and the salary of his employees in the midst of the crisis caused by the COVID-19 pandemic. How should the delivery service be configured to keep Casa Porto going without giving up both the learning he received throughout his life and his way of being an entrepreneur?

\section{HOW IT ALL STARTED}

Born in the north of the city, from where he drew inspiration for part of the menu offered today at Casa Porto, Raphael left home at the age of 13 to move away from an adverse home environment and went to live with his uncles. At the age of 16, he entered the Faculty of Philosophy, located in the center of Rio de Janeiro. In an attempt to find a way to support himself and follow his two great dreams - to personally meet famous writers and, one day, become one of them - , he started to write what he called the "Letters of existence". The letters were sold in envelopes for reading at different times of everyday life, such as on the bus or at home before bedtime.
At the age of 18, taking advantage of the 2000s internet boom, he conceived and set up with some friends a short story magazine called Bagatelas, which gathered content from young Portuguese-speaking writers. He became the editor of the magazine and, after his dissemination effort (from a fictitious press officer created by himself), he began to have his tales published in newspapers of great circulation as well as to have his name present in small notes in the newspapers.

Equipped with a portfolio of his tales and newspaper clippings, Raphael decided to talk to Marcelo, owner of a bookshop located within the Imperial Palace, which entry was long ago his point of sale of the "Letters of existence." He shared with him his idea of promoting a round table with writers, an event for which he would need the space of the Imperial Bookshop. With Marcelo's endorsement, and with advertising promoted by newspapers, he managed to perform his first event with the writer Sérgio SantAnna. The event was informal and based on a morning and afternoon of chatting and drinking beer. With the maximum capacity of the space occupied, the first edition of Encontros \& Bagatelas was considered a success by the participants and organizers.

Marcelo then decided to bet on the potential of Raphael and proposed him the job of administrator. That space allowed Raphael a fruitful experience as a bookstore employee. Marcelo treated everyone with dignity and respect and showed the dignified side of work. "This guy taught me how to treat employees," declared Raphael.

However, despite the numerous initiatives they both took together, the bookstore was unable to keep running. Raphael was then nominated by Marcelo for a post in a large bookstore in Leblon. However, soon after a brief period, he found himself dissatisfied with the way the employees were treated there and began to seek opportunities to work as an editor, getting a job at Vieira \& Lent publishing house.

At the time, Cilene Vieira admitted Raphael even though she knew he did not actually have any knowledge about editing. Cilene became, alongside Marcelo, the "second pillar of ethics" and reference to what Raphael claimed to do at Casa Porto.

With this job, and just over 20 years old, Raphael fulfilled his dream of entering the editorial market. Cilene Vieira taught Raphael everything she knew. More than technical skills in the area of editing, Cilene taught him, by example, that it was possible to be efficient and treat employees with humanity.

However, due to the economic crisis of 2008, that small publisher of scientific dissemination closed its doors, and Cilene had to fire Raphael, but not before nominating him for a new job, like Marcelo. Raphael became editorial 
coordinator of a larger and better-known publisher. Excited at first, Raphael soon became disappointed with the way people management was carried out. The context of dissatisfaction with the work environment in the new publisher led Raphael to decide to set up the project of a literary festival in Morro da Conceição, inspired by the round tables promoted in the Imperial Bookshop: The Book Weekend in Porto (FIM). He aimed at showing the public that intellectuality resided in books and in what the writer had to be teach: "how to live life."

In 2012, the FIM project was ready, but lacked money and experience for execution. Based on his charisma and commitment, Raphael obtained, in a short time, the sponsorship of the city hall, the dialogue with several publishers, and the financial support from Light. With money in hand, he activated his contacts and acquired the support of great names in the branch of press relations and cultural production: Claudia Noronha and Bel Fernandes, respectively press officer of MAM and producer of Anima Mundi who, without charging for the service, bet on the project. "It was the last pillar of professional learning, of how to deal with an entrepreneurial relationship," Raphael said. On the one hand, Bel taught him all about production, and on the other, Cláudia made him known with the dissemination of the FIM.

House rented and transformed into a pub scenario, and famous writers (with names like Nei Lopes) invited to chat and drink beer, suppliers and artists from the region publicizing the festival and exercising their work during the event: the FIM was a success.

The day after the event, Raphael received a proposal to work as cultural producer at the Rio Art Museum (MAR), which was scheduled to open in 2013, at Praça Mauá. At the same time as it was an opportunity never imagined, Raphael remained restless and feeling that FIM changed him definitively.

\section{THE CASA PORTO}

One day, outside the museum, sitting in a bar, he ran into a neighbor who was on his way to the real estate agency to return Casarela: a house that had been used to promote parties and as a deposit of drinks sold at the event Slaves of Mauá. Upon learning of the delivery of the property, Raphael rented the place for $R \$ 600.00$ and from there went directly to MAR negotiate his resignation. With the money of the termination, Raphael renovated the house and presented to Porto Maravilha ${ }^{3}$ a project to open a cultural center for training residents of the region. After all, for the execution of FIM, he had mapped people who worked with cooking and who made culture in the region, but who needed training to climb a step on professional life.
This is how Casa Porto was born. With the monthly sponsorship of Porto Maravilha, the cultural center operated with workshops and courses during the day and had presentations of students at night. An environment still without a kitchen, where beer was sold and cultural activities were held (see Annex A).

The cultural project at Casa Porto worked and the initiative yielded awards and new sponsorships over four years. However, after the World Cup and Olympics events, Rio de Janeiro went into crisis, along with the end of the Porto Maravilha project and, in sponsorships, Raphael found himself in debt and facing another challenge.

\section{CASA PORTO AFTER THE END OF THE PORTO MARAVILHA PROJECT}

Reflecting on how to get around that moment, while without much success renting the space for parties and shows, Raphael thought of his passion for cooking, facet that had also made him known to the point of being invited to gastronomy events and as a jury of competitions around the city. He had a passion for welcoming friends, for those who cooked, especially on Sundays, but also for promoting bars, on the internet. This is how, in early 2018, he transformed Casa Porto into a pub. But it needed to generate an attraction to encourage passers-by to climb the stairs of the house to delight the environment.

With an eviction order in the middle of Carnival, Raphael received help from a lawyer friend (another 'angel' in his life) to keep the rental contract of the property of Casa Porto. The menu of the pub was then disclosed with the famous ham coxinha that his grandmother used to make, highlighting the gizzard that had also been his cheap meal in a downtown pub throughout the faculty of Philosophy. But he didn't mean to serve a common plate of gizzard. To encourage the climb of the steps of the stairs in that discreet little street, which shared space with other bars on the sidewalk, something different should be offered. He then launched his Milanese gizzard.

Raphael cooked using only one camping stove with a mini canister, torch, and microwave. He had the bet of beer suppliers, with whom he still cultivated debts of the previous phase of Casa Porto, and the support of friends of the branch, from whom he won tables, chairs, refrigerators, and from the cookers of the region, bar owners and friends. And on March 5, 2018, Casa Porto reopened its doors, strengthened by the collective support movement. Thus, even in the face of initial difficulties, once again the idea of Raphael was successful and began to be disseminated on the social network Facebook. In June of that same year, Raphael 
was already beginning to pay off his debts and make Casa Porto, a pub version, known.

With increasing demand and revenues, Raphael reformed the kitchen and felt the need for a greater contribution of resources. One day, in a conversation with an acquaintance, Raphael met a person who would become his partner and who would later bring another colleague who would also act as second investor partner. Among the three, Raphael would be the one acting directly at Casa Porto, having full autonomy for decision-making. "Today, I have an idea and I do it. If I offered a dish and didn't sell it, tomorrow I'll make another one. I have no commitment to everything to work out. My only commitment at Casa Porto is to make it a place of experience. It's the place I'd like to go to ... that sells nice, tasty food, but that has symbolism. It attracts customers who have also become friends," says Raphael.

And that's how Casa Porto kept the face of its creator. Those who followed the posts on social networks such as Instagram and Facebook, in 2020, imagined that Raphael would have a team dedicated to it. In fact, Raphael had been doing everything himself, answering each comment, posting each photo, and writing each publication. "The Casa Porto Instagram is me," said Raphael. In his creative posts, Raphael had fun playing with friends, talking politics. "I started in March 2018 with 50 followers, and today we have 27,000." His promptitude with the use of social networks guaranteed his proximity to customers, an aspect highly valued by Raphael in his business.

The contents were being enriched by what Raphael lived in the daily life at Casa Porto, where he chose to be the chef, creating menus and recipes, a role accumulated with that of administrator. Raphael understood that his administration was not based on technical training, but in instinct and in his ability to be self-taught, as he was in many moments of his career.

In this context, he considered that his relationship with the team, formed by 19 people, was the result of everything he experienced throughout his life. "There would be no other option for me to deal with the team because of ... all the frustrations I've experienced and all the positive relationships as well. So, I wanted to bring it to Casa Porto. I've been acting based on my gut feelings. But today I see that it was the fruit of everything I've been living, that I've been going through. So, I wanted to set up a company where people felt at ease and satisfied. Just as I felt in the Imperial Bookstore with Marcelo and in Vieira \& Lent publishing house with Cilene."

Among the practices of people management at Casa Porto, Raphael cited: open bar for employees, advance salary for those who are going through some difficulty, encouraging the relationship of equality between employees with different profiles, involvement of all in important decisions. This culture created in Casa Porto made that the only layoffs that occurred until 2020 were motivated by situations of disrespect, unadmitted on the site.

"A humanized relationship with employees, for me is the only possible option," said Raphael. "I make [Casa Porto] my passion ... The employees are the base of the house. So, when I'm not there, they represent Casa Porto." Three team employees were clients who frequented Casa Porto and asked to join the team. "They are company man because they are part of it ... it is difficult to find something like that," Raphael describes.

\section{THE CRISIS OF COVID-19 AND THE NEED FOR REINVENTION OF CASA PORTO}

As soon as the joy of Carnival had passed, the month of March 2020 was dominated by warnings about the crisis of the pandemic of COVID-19 and its reflections in Brazil. In an advanced stage in other countries in Asia and Europe, here it gained accelerated dimensions.

The decision to close the doors was inevitable and became mandatory for many establishments by government guidelines, which kept the opening permit only for those considered essential services such as supermarkets, pharmacies, gas stations.

Worldwide, quarantine measures guided by the World Health Organization (WHO) due to the progress of the pandemic have led to a restriction on the movement of people, with consequent impacts on economies ${ }^{4}$.

According to the Brazilian Association of Bars and Restaurants (Abrasel), the bar and restaurant sector was one of the most affected by quarantine measures and consequent restriction in the circulation of the population. The potential impact on jobs in the sector was worrying. Paulo Solmucci, President of Abrasel, stated in a March 2020 publication ${ }^{4}$ : "We are 1 million establishments, 65\% do not even have CNPJ, and $80 \%$ of them make less than R $\$ 20$ thousand per month and have a maximum of two employees. This $80 \%$ generates about $20 \%$ of the sector's revenues, of the order of R \$ 250 billion, but are responsible for almost half of the jobs."

Some establishments managed, at least in the initial phase of the door closing process, to keep employees away, without deciding to immediately dismiss them. Others chose to anticipate employee sit-ins in an attempt to postpone larger losses ${ }^{4}$.

But, without revenue, the maintenance of the business and employees began to require alternative decision-making by the owners of bars, restaurants, and nightclubs, while remaining closed. Vouchers anticipating payments for the enjoyment of customers after the reopening of establishments, 
subscriptions, promotions, maintenance of interaction with customers, especially via social networks, until the call of part of the teams to support the execution of some services, were among the alternatives triggered by many establishments, including Casa Porto.

After making use of several strategies, such as Inverted Rain Check, the support to the delivery scheme was the only possible option identified by Raphael to keep the payment of his employees for longer. With rapid adaptation, characteristic of Raphael, and with the support of the newly hired 'project manager,' who since January 2020 helped with the execution of creative ideas for the business, the decision to be made was clear, as well as the understanding that only employees who lived in the region could act on this front, moving on foot to Casa Porto.

Although he was not getting enough money for his own livelihood, Raphael had as a primary concern to preserve the health of his employees. His definition of health went beyond the issue of the risk of contamination by COVID-19: he felt responsible for offering a sense of security to his team, leading them to rely on the preservation of their jobs and salaries in order to minimize the uncertainties generated by the context of the pandemic.

The tension of providing security in the midst of a period of great instability was enormous. However, even with his own practical and emotional difficulties, even with sleepless nights, Raphael's responsibility to his team made him follow in search of solutions to the challenge he was facing.

And meanwhile the deliveries were ensuring the initial livelihood of Casa Porto, to the point of not having to fire anyone, Raphael was dissatisfied with the support to the use of applications for some reasons:

a. Delivery perimeter - given the location of the establishment in the Port Zone (Annex B) and how the applications work, the delivery radius was limited to some neighborhoods that went from Glória to Maracanã. The 'loss' was aggravated by the fact that the surroundings of Casa Porto itself did not represent a potential delivery-consuming region, because it is a predominantly commercial region, that is, lacking a potential consumer public during the pandemic.

b. Fees charged - when choosing the modality that includes the delivery service by the application (Annex C), the fee charged ranged from $22 \%$ to $30 \%$ of the order value, strongly impacting on the final revenue derived from sales.

c. Impossibility of direct access to the final consumer the absence of direct contact with consumers affected the way of work with which Raphael had become accustomed. Proximity to customers was synonymous with new ideas and thermometer to improve the menu and the business. The evaluation of the delivery service itself was impaired by the use of applications.

d. The working conditions of the deliverymen - the knowledge of how delivery services worked led Raphael to understand it as precarious. In addition to the low remuneration received by professionals with each delivery, leading them to fulfill strenuous working hours (often exceeding 12 hours of work daily to ensure a minimum income of sustenance at the end of the month), the absence of insurance or guarantees in case of illness or accident, the costs of equipment for the realization of deliveries (such as backpacks with the brand of applications, and for protection against contamination by COVID-19) being borne exclusively by the delivery workers justified the perception of precarization. In addition, when reading reports on the impact of applications for small businesses, for example, in the $B B C$ News Brasil, São Paulo on February 8, 2020, Raphael began to question even more whether the partnership would be beneficial or not for the maintenance of Casa Porto.

It was three o'clock in the morning of April 8, 2020 and Raphael had not yet been able to sleep. Three weeks passed since the closing of face-to-face service and the start of the application delivery service. Some of the nearby restaurants decided to close the doors temporarily, others definitely. A decision had to be made urgently. He knew that he was going to act to change the way he was providing the delivery service. But what to do? Among the numerous projects that bubbled in Raphael's ever-restless head, he began to think of having his own fleet of deliverymen. But how to distribute the tasks among the employees? What partnerships should be established? What tools to use? Would there be any alternatives besides the formation of a fleet of deliverymen? The only thing Raphael knew was that closing the doors definitely wasn't an option.

\section{NOTES}

1. RJ registra 92 mortes pelo novo coronavírus. G1. Retrieved from https:/g1.globo.com/rj/rio-de-janeiro/noticia/2020/04/08/casosde-coronavirus-no-rj-em-8-de-abril.ghtml

2. Coronavírus: Bares do Rio se reinventam para não fecharem as portas e agradar clientes. O Globo. Retrieved from https:// oglobo.globo.com/sociedade/coronavirus-servico/coronavirusbares-do-rio-se-reinventam-para-nao-fecharem-as-portas-agradarclientes-24315164

3. Urban revitalization project of the Port Region of Rio de Janeiro involving the Public Power and private initiative.

4. Coronavírus e o bolso: "Ninguém que está vivo no Brasil hoje viu algo tão sério". Agência de Jornalismo Investigativo. Retrieved from: https://apublica.org/2020/03/coronavirus-e-o-bolso-ninguemque-esta-vivo-no-brasil-hoje-viu-algo-tao-serio/ 


\section{ANNEX A. CASA PORTO ACTIVITIES}

"The activities, always free, aim to share the cultural riches through thematic events, with the participation of special guests. The week begins with Silence in the Library, where writers, editors, or booklets chat about the world of books. On Tuesdays, it is the turn of the Art of Encounter, always with artists from the port region (filmmakers, musicians, artists) who talk about their works. On Wednesdays, the Bahian Board takes place, focused on Afro-Brazilian culture, when guests hold debates and workshops of rhythms and dances. On Thursdays, the House receives projects of all artistic expressions, always presenting a novelty, such as the workshop Passos Populares, which has already made many people dance the jongo, or the Rio Web Fest show, an international festival of web series. To close the week, Friday is free, and the House works only as gallery, café, and bar, but that can always surprise, as in a creative action made especially for children.

Casa Porto also carries out the Porto Criativo program, a project-consulting incubator for residents of the region. The service is free and the House shares a structure with high-speed internet, air conditioning, work desk together, rest room, library with 5,000 titles and some virtual, auditorium equipped for meetings and lectures, in addition to providing consultants and promoting experiences and disciplinary activities.

Other events, such as June parties and celebrations, are always being produced to also occupy the Largo da Prainha and surroundings, attracting public from other neighborhoods and generating income for residents. One of the great highlights is the Book Weekend in Porto (FIM), a literary festival of great success, which has already had three editions.

With the suggestive slogan 'Ideas of open doors,' Casa Porto deserves full support for the relevance of its activities that have been transforming the reality of cariocas, especially that of the residents of the region."

Source: http://guiaculturalcentrodorio.com.br/casa-porto/, retrieved on July 13, 2020. 


\section{ANNEX B. LOCATION OF CASA PORTO}

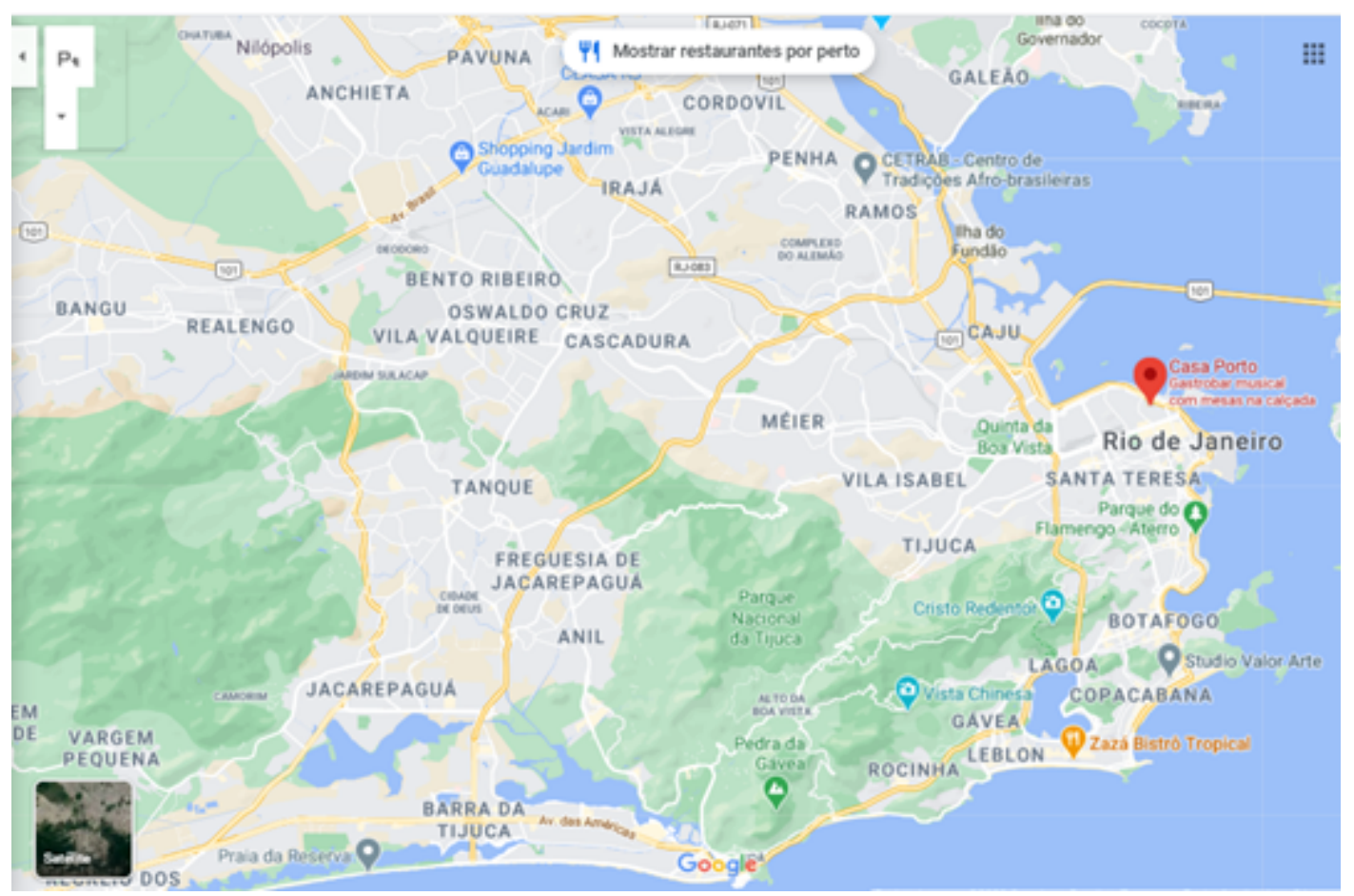

Figure B1. Location of Casa Porto.

Source: Google Maps. 


\section{ANNEX C. IFOOD PLANS}

\section{Basic Plan}

- Delivery made by restaurant

- Rate of $12 \%$ on the value of all orders and $3.5 \%$ more on orders with payment via iFood

- Monthly fee of $\mathrm{R} \$ 100$, only if you make more than $\mathrm{R} \$ 1,800$ monthly.

\section{Plano Entrega}

- Delivery by iFood partner delivery companies

- $27 \%$ rate on the value of all orders

- Monthly fee of R\$130, only if you make more than R\$1,800 per month

Source: https://parceiros.ifood.com.br/restaurante retrieved on July 13, 2020. 


\section{Teaching Notes}

\section{ABSTRACT}

This teaching case describes the trajectory of the entrepreneur Raphael Vidal. The information presented makes it possible to link the history and beliefs of the subject-entrepreneur Raphael to the decisions regarding Casa Porto project in the context of the COVID-19 pandemic. Aspects of his entrepreneurial attitude as a basis for the way he has been conducting Casa Porto are exposed. In addition, elements related to the decision to open, conduct, and maintain a business in situations of crisis are displayed. And more importantly, nuances related to other spheres involved in the understanding of the entrepreneur as a social being are addressed.

Keywords: teaching case; entrepreneurship; humanized entrepreneur; COVID-19; crisis.

\section{RESUMO}

O caso de ensino descreve a trajetória do empreendedor Raphael Vidal. As informaçôes apresentadas possibilitam vincular a história e as crenças do sujeito-empreendedor Raphael às decisóes referentes ao empreendimento Casa Porto no contexto da pandemia do COVID-19. Aspectos de sua postura empreendedora como base para a forma como vem conduzindo a Casa Porto são evidenciadas, assim como são resgatados elementos relacionados à decisáo de abrir, conduzir e manter um negócio diante de situaçôes de crise. Adicionalmente, são abordadas nuances relativas a outras esferas envolvidas no entendimento do empreendedor como um ser social.

Palavras-chave: caso para ensino; empreendedorismo; empreendedor humanizado; COVID-19; crise.

\section{DATA SOURCE}

The case was written from secondary information obtained on various websites (referenced), in an interview conducted with Raphael Vidal himself, and in multiple text, audio, and video messages exchanged with the entrepreneur via emails and WhatsApp throughout the construction of the case. The case has an authorization from Raphael Vidal for publication.

\section{EDUCATIONAL OBJECTIVES}

The present case aims to allow students to understand aspects involved in the generation of a new business, highlighting the role of the entrepreneur, and the impact of his style, social subject, in the decision-making process in crisis contexts.
The proposal is to make students analyze Raphael Vidal's entrepreneurial trajectory and discuss the possible alternatives for his business in a pandemic context, proposing solutions consistent with the profile of the humanized entrepreneur to the dilemmas portrayed.

The case was developed in order to enable the exploration of concepts related to entrepreneurship and people management, and can be applied in undergraduate courses in Administration, in disciplines of Entrepreneurship, Organizational Behavior, Service Management, or any other discipline that addresses the topics discussed here. 


\section{LESSON PLAN}

For the conduction of the activity, the following steps are suggested:

- Availability of the material: it is proposed that the professor make the case available to the students at least one week in advance of the class.

- Individual prior preparation: it is proposed that the professor request that the students read the case and prepare a small report before the class, of at least one page, with the main information of the case, including the dilemma faced by Raphael Vidal about the delivery service during the pandemic. The individual report should be taken to debate in small groups.

- Discussion in small groups: it is proposed to divide the class into groups of at least three and a maximum of five students for the discussion about the case in the search for solutions to the problems presented.

- Plenary discussion: a debate is proposed with the whole class. Each group must present its ideas and propositions. It is advisable that the professor stimulate the debate through auxiliary questions that encourage students to describe and clearly defend the proposed solutions and the presented views. Examples of auxiliary questions: Could you please better describe the point $\mathrm{x}$ of your proposal? Why do you think Raphael should act this way? What is the coherence between your proposal and Raphael's trajectory? What would be the purpose of this initiative? What do you expect Raphael to achieve by doing this?

\section{PLANNING SUGGESTION FOR CASE DISCUSSION}

Dilemma: Raphael wondered how he could keep his business and the salary of his employees amid the crisis caused by the COVID-19 pandemic.

Warming up for discussion in small groups: Describe Raphael Vidal's various professional decisions and initiatives throughout his life. What do they say about Raphael's motivations and his way creating new business ventures?

Issues for plenary discussion: (1) Given the context presented by the case 'Casa Porto,' what solution do you propose for the enterprise? Detail your proposal and explain to what extent your solution is consistent with Raphael Vidal's life trajectory/life story; (2) Highlight Raphael's main individual characteristics that influenced him in his lifelong decisions regarding business ventures.

\section{THE ANALYSIS OF THE CASE AND ANALYSIS/TEACHING PROCESS}

The case can be used to introduce theories on humanized entrepreneur and entrepreneurial profile. The Table 1 synthesizes the organization of a class lasting two hours.

Table 1. Lesson plan.

\begin{tabular}{lc}
\hline \multicolumn{1}{c}{ Lesson plan } & Duration \\
\hline Introduction and division of small groups & $20 \mathrm{~min}$ \\
Small group discussion & $30 \mathrm{~min}$ \\
Plenary discussion and introduction of theory & $60 \mathrm{~min}$ \\
Closure & $10 \mathrm{~min}$ \\
\hline
\end{tabular}

Plenary discussion - Part 1

The plenary session should be initiated with the question (1) that refers to Raphael Vidal's dilemma: Given the context presented by the case 'Casa Porto,' what solution do you propose for the enterprise? Detail your proposal and explain to what extent your solution is consistent with Raphael Vidal's life trajectory/life story.

We suggest that in the first part of the discussion a focus should be given on the solutions proposed by the students and Raphael's life trajectory to establish the connection between the case and the theory of humanized entrepreneurship. As students are presenting their ideas, the professor should write down on the board, in the PowerPoint, or in any available tool, the elements presented by the participants in order to use this information to introduce the concept of humanized entrepreneurship and to identify Raphael as a humanized entrepreneur.

It is not necessary for students to reach a consensus, just that the participants: (a) demonstrate that they understood the context and the dilemma; (b) propose and defend the solutions presented; (c) argue the relationship between their proposals and Raphael's characteristics and his life trajectory/life history.

\section{Theoretical Contextualization - Humanized Entrepreneurship}

The phenomenon of entrepreneurship prevents it from being reduced to simply opening a company. Therefore, a multidimensional view of the phenomenon is advocated (Danjou, 2002), as well as regarding the definition of 'entrepreneur,' which varies according to the epistemological lenses used over time (Guimarães, 2019). 
In this attempt to offer a multidimensional perspective of the phenomenon of entrepreneurship, both the issue of subject-entrepreneur subjectivity and its ability to be a reflective subject with actions endorsed with meaning are rescued (Schön, 1995). In addition, relevance is given to the emotional and experiences aspects (which for some studies are evidenced by the use of the method of investigation of the subjects' life history), not always included in investigations in the field of organizations (Gaulejac, 2005; Legrand, 1993; Paiva, Almeida, \& Guerra, 2008).

The concept of humanized entrepreneur arises in the context of a critical reading about the entrepreneurial phenomenon, as opposed to the utilitarian and individualistic reading commonly employed (Paiva et al., 2008).

The basis of the concept lies in the understanding that the multiple relationship with the other is the basis for the constitution of the human being and the humanized entrepreneur who "is in constant social construction of reality as refinement of himself and others, involved in his project director" (Paiva et al., 2008, p. 119).

Therefore, from the point of view of an interactionist perspective, it is understood that in addition to individual characteristics, it should be taken into account that the constitution of the entrepreneur is strongly based on the relations he maintains with the other. "The humanized entrepreneur emerges as a relational being, instead of the lone hero" (Paiva et al., 2008, p. 120), a view that contradicts the psychosocial current of the subject-entrepreneur to that of the atomistic entrepreneur.

Additionally, it can be said that the humanized entrepreneur has a commitment to the experience lived in the dimensions of past, present, and future, which leads him to rescue a meaning in his social, family, and work relationships. In this context, it "integrates the objectivity of work with the subjectivity of the person and also demonstrates social responsibility with reality" (Chanlat, 1996 as quoted in Paiva et al., 2008, p. 127). Starting with Lester, this entrepreneur presupposes the practice derived from experience, allowing pointing out other relationships of human interaction, with regard to always starting over, creating and recreating. This seems to presuppose the existence of responsibilities and construction stemming from a bet on self-confidence.

\section{Analysis of Raphael Vidal's profile as a humanized entrepreneur}

An analysis of Raphael Vidal's entrepreneurial style can be performed based on the decisions made in the positions of enterprising subject, and rescuing aspects and facts of his life trajectory. His performance, even before transforming Casa Porto into a bar, reveals an entrepreneurial action of an engaged nature with dimensions of social reality. Supporting the local community and encouraging business in the surrounding area are part of the everyday life and of his entrepreneurial logic.

The relational dimension (Paiva et al., 2008) is a remarkable feature in Raphael's story, having been the basis for the construction of his entrepreneurial profile and source of learning that he says he takes to his current business. In addition, it was an important source of cultivation of nonutilitarian posture, allowing Raphael to always walk in the direction of his idealized project.

Both with Marcelo, owner of Imperial Bookshop, and with Cilene (Vieira \& Lent), Raphael declared to have learned 'how to treat the employee,' 'the worthy side of the work,' the value of a generous posture to invest in someone who does not have total experience in the branch (as a bet), and to support people in difficulty (either at the time of job search, or when leaving it). "All I'm doing now is just reproduction of what I lived with Cilene and Marcelo. They're the two people who are references in my life on how it's possible to have a look at the employee beyond the business issue, you know, the question of the outcome, you know, of financial outcome," states Raphael.

This learning was reinforced with his relationship with several key actors for FIM to happen (from sponsors to great names of press relations and cultural production), in a context in which the human relationship prevailed, as well as the belief in the viability of a enterprise without resources, over the utilitarian, financial dimension.

These dimensions learned throughout his career made Raphael also maintain the desire to treat his employees with respect, equality, and justice. Offering employees open bar during office hours has an important symbolism and reflects Raphael's desire to make the work environment a harmonious space, without the weight of the formal structures commonly found in organizations. In addition, the "salary advance for those who are experiencing some difficulty, encouraging the relationship of equality between the 19 employees with different profiles, involvement of all in important decisions" also reflect the intention to treat his team in a caring way.

As for the decisions made along his career, his restless, demanding aspect, which does not settle down in the face of thought and postures regarded as hegemonic in the organizational world, allow the understanding of Raphael as a humanized entrepreneur to be strengthened. Jobs or stable sources of income, such as at MAR, or in Leblon bookstore, did not allow him to give up his beliefs in what would in fact be correct from the point of view of employment relationship and what could give meaning to the work he did. Paiva, Almeida and Guerra (2008) describe that this 
emancipatory posture of the humanized entrepreneur, however, requires time, so that there is no radical rupture with the sociocultural conditions of the entrepreneurial environment providing a space/time of adaptation.

In the pandemic context, his posture was no different: "They were the only possible attitudes. The only thing I could do was quarantine at home the team that takes public transportation. The only thing possible. It doesn't go through your head. For all the experience I've been through in my life," says Raphael.

Raphael sees no sense in being an entrepreneur, if not with the thought of the welfare of those around him. And it goes beyond the group of employees, including the wellbeing of the community where it is inserted.

\section{Alternatives of Action - Humanized Entrepreneurship}

By conducting the discussion on the possible solutions to the dilemma faced by the entrepreneur in the case, the professor should help the participants analyze how much the proposals presented escape from the traditional, utilitarian, pragmatic and self-confidence-based individualist approach. The students should also incorporate aspects of human interaction and the responsibility of the entrepreneur with his employees in the face of the challenges imposed by the pandemic context.

In this sense, the solutions could approach the humanist approach to the extent that they consider one or more of the following elements: dignified treatment and support to employees at times of difficulty, the reality of the community surrounding the restaurant, the job opportunities that could arise with the proposed solution, Raphael's emancipatory stance in the face of hegemonic structures and practices, the informality and creativity of the entrepreneur, the way Raphael builds and maintains his partnerships with employees, suppliers, and customers, as well as his commitment and charisma to obtain support and sponsorship.

Closing the deal was not an option for Raphael. Among the possible alternatives at that time, he could:

1. Try to maintain the use of iFood and Uber Eats due to the visibility they provide, but use his own fleet for delivery, thus reducing the fees charged and ensuring a fair treatment of deliverymen. The fleet could be composed of residents around Casa Porto.

2. Create his own application or means to receive and manage orders and deliveries, making it more independent of big applications.
3. Leverage sales through a direct approach with loyal customers to Casa Porto through social media.

4. Temporarily close the doors and maintain the business by financing through 'virtual kitty' or by the sponsorship of one of the new partners or another person from Raphael's network.

\section{Plenary discussion - Part 2}

We suggest that in the second part of the discussion, a focus is given on Raphael's main individual characteristics that are in accordance with the theories of entrepreneurial profile from the question:

1. Highlight Raphael's main individual characteristics that influenced him in his lifelong decisions regarding business ventures.

As students are exhibiting their ideas, the professor should write down on the board, on the Power Point, or in any available tool, Raphael's individual characteristics highlighted by the students, focusing his attention on identifying the elements that help illustrate the impact of Raphael Vidal's individual characteristics on his entrepreneurial decisions.

\section{Theoretical Contextualization - Entrepreneurial Profile}

\section{For Shane and Venkataraman (2000),} entrepreneurship is the field of studies on how, by whom, and with what effects opportunities to create future goods and services are discovered, evaluated, and exploited. As a result, studies on entrepreneurship should cover the discovery, evaluation, and exploration of opportunities as well as the group of individuals who discover, evaluate, and exploit these opportunities (Shane \& Venkataraman, 2000; Shook, Priem, \& McGee, 2003).

Shook, Priem and McGee (2003) highlight the role that the characteristics of the individual, the entrepreneur, play in the stages of formation of an enterprise entrepreneurial intention, search and discovery of opportunities, in the decision of exploration and in the activities involved in the exploration until the first sale.

About entrepreneurial intent, that would be the intention to create a business, Shook et al. (2003) observe that the literature on the subject focuses on individual perception of the possibility, will, and social supports for the beginning of a new business. Autonomy, demographic characteristics, and self-efficacy are presented as important factors for the development of entrepreneurial intention. 
Shane and Venkataraman (2000) define opportunities as "situations in which new products, services, raw materials, and organization methods can be introduced and sold at a higher price than the cost of production ... requires the discovery of new relationships between means and ends" (Shane \& Venkataraman, 2000, p. 220). Therefore, the idea of opportunities would be linked to the idea of creating something new. In this sense, entrepreneurship does not require, but can include the creation of new companies.

In addition, according to Shane and Venkataraman (2000), a discovery would occur when "someone makes the conjecture that a set of features is not placed in its "best use" (Shane \& Venkataraman, 2000, p. 220). Two factors would influence the discovery: the possession of information to an opportunity; and the cognitive properties needed to value it.

On the decision to explore an opportunity, Shane and Venkataraman (2000) highlight both the characteristics of the opportunity and the nature of the individual. Opportunities with higher expected value would be those exploited. The differences between the individuals would contemplate: weighting between the value of the opportunity and the costs to generate this value and to generate value in other ways; the costs of obtaining the resources needed to exploit the opportunity; strong social ties with resource providers, which would facilitate the acquisition of resources and increase the likelihood of exploitation of opportunities; the development of useful information for entrepreneurship from a previous job; the transfer of information from the experience prior to the opportunity; previous entrepreneurial experience. The decision to explore an entrepreneurial opportunity would also be influenced by individual differences in perceptions, in the willingness to bear risks, in optimism, in greater tolerance of ambiguity, and in the greater desire for fulfillment. Finally, according to the authors, people with greater self-efficacy and internal locus of control would be more likely to explore opportunities. Shook et al. (2003) highlight the propensity to risk, motivations, and attitudes as psychological attributes as possible influences in the decision to explore an entrepreneurial opportunity.

\section{Raphael Vidal's analysis according to the entrepreneur profile theory}

A way to identify Raphael Vidal's entrepreneurial profile can be the analysis of his individual characteristics that influenced the decision to explore the entrepreneurial opportunities that have emerged throughout his life.

Some of the psychological attributes highlighted by Shook et al. (2003) - propensity to risk, motivations, and attitudes - and the individual characteristics pointed out by Shane and Venkataraman (2000) - willingness to bear risks, optimism, greater tolerance to ambiguity, greater desire for achievement - can be identified in Raphael's trajectory.

The search for the dream of knowing and living with writers, working in the publishing market, and becoming a writer is present in his accounts and in his life history. Faced with the difficulties and numerous complex risky choices, the entrepreneur maintained optimism and a desire to accomplish his ideals.

Additionally, Raphael's propensity to bear risks is striking and evidenced several times in his trajectory. Among the evidence in the case, we can highlight:

- Leaving home at the age of 13 .

- Resigning or planning to leave jobs whenever he was dissatisfied, even without being able to predict whether his next move would be successful or not. Examples: when he was seeking opportunities in publishers while working in the bookstore in Leblon, when negotiating his departure from MAR, when leaving his job at a large publishing house to start the Literary Festival project in Morro da Conceição (FIM).

- Willingness to seek opportunities for work and projects in which he had no experience, but endowed with an immense desire to learn and to accomplish ideas. He did so when: (1) he presented himself to Marcelo, owner of the Imperial Bookstore and began a management job without ever having had such an experience; (2) sent his resume to several publishers until he was hired by Cilene, despite his absence of baggage as an editor; (3) set up the project of a Literary Festival in Morro da Conceição (FIM) and obtained the necessary sponsorship despite his inexperience with the branch of production of events of such size.

Shane and Venkataraman (2000) also point out that strong social ties with resource providers facilitate their acquisition and increase the likelihood of exploring new opportunities. Raphael Vidal, throughout his entrepreneurial career, has demonstrated skills not only to activate his potential network of suppliers and investors, but also to create the necessary bonds of trust with suppliers and sponsors for the implementation of an enterprise.

Among the evidence of the case we can mention: Marcelo's support for the chat with writers project; obtaining and sponsoring (City Hall, Light), production support (Cláudia Noronha and Bel Fernandes), and operational support (workers in the region) for the FIM project; obtaining resources to make Casa Porto a cultural center, which included among its activities the professional training of the local workforce, further strengthening the ties between the entrepreneur and local service providers; 
the help of a lawyer friend who provided him with advisory services so that he could stay in the property in a period of difficulty; good relationship with beer suppliers, restaurant owners, and cooks in the region, and friends who helped him reopen Casa Porto as a pub; the financial contribution of two partners who invested in Raphael's dream.

Finally, the development of useful information for entrepreneurship from a previous job, the transfer of information from the experience prior to the opportunity, and the previous entrepreneurial experience (Shane \& Venkataraman, 2000) are also present in Raphael's story. Although the trajectory of this entrepreneur is characterized by the diversity of activities in multiple jobs and enterprises, the accumulation of experiences related to the area of culture helped him develop technical and interpersonal skills that manifested themselves mainly in the decision to start and maintain the project of Casa Porto.

The experience with the FIM project helped him in the formatting of Casa Porto as a cultural center and his passion for cooking was important when the enterprise was transformed into a pub. Nevertheless, previous jobs with Marcelo and Cilene were, according to Raphael himself, essential references on how to treat employees with dignity and respect.

\section{CLOSURE}

Casa Porto is not just a business for Raphael, it is an extension of his life. Prior to the COVID-19 pandemic, he did not work with delivery, but joined the service as the vast majority of restaurants did to circumvent government restrictions on public service.

Dissatisfied with the delivery application fees and outraged by the precarious conditions to which the deliverymen were subjected, Raphael decided to set up his own delivery fleet with the help of his newly hired project manager.

Although he had no experience in managing the new idea - as had happened so many other times in his career - Raphael noted that motorcycle taxi drivers around the Port Zone were idle and called two friends who lived near Casa Porto (a motorcycle taxi and an Uber driver) and began his independent delivery service with a larger perimeter than the one used by the apps, arriving in regions such as Gávea and Meier. To support, he set up a specific WhatsApp structure for independent orders, allowing orders to be received by the waiters, responsible for administering the delivery service.

The idea was to maintain the application platform, but prioritize the use of the independent fleet. In two weeks, demand for iFood and Uber Eats platforms accounted for only $5 \%$ of orders. On his social networks, Raphael intensified contact with his customers to ask for support for his business and to strengthen the delivery channel itself. His efforts yielded results that were reflected in higher margins, lower costs, and an increase in the number of requests. This action, together with the return of the Inverted Rain Check, guaranteed the advance of employees' salaries until August 2020 and the hiring of three new employees.

Three months after the start of the service, Casa Porto started to have a fleet of seven motorcycles and one car that reached more than a thousand deliveries in June with the support of the platform Delivery of Good. All the deliverymen obtained a monthly income of around $\mathrm{R} \$$ $1,400.00$ for a weekly workload of 40 hours. In addition, Casa Porto guaranteed the supply of lunch and snack, basic food basket, accessory equipment (cell phone support, backpack bag, mask, alcohol gel, spine strap), awards, among other benefits. Raphael met the team every Tuesday and demonstrated his concern for the deliverymen, actively listening to their demands and thinking of solutions to the new challenges.

The initiative yielded financial return and Casa Porto began to record sustained revenues. In the second half of March, revenues were R\$21,649.00; in April, the month in which the independent delivery service began operating in the second half, revenues were $\mathrm{R} \$ 69,300.68$; in May and June, revenues were $\mathrm{R} \$ 70,786.87$ and $\mathrm{R} \$ 98,975.73$, respectively.

However, given the uncertainties generated by the pandemic crisis, Raphael observes and evaluates his next steps to act in favor not only of the perpetuation of his enterprise, but also of support for the surroundings and restaurants and businesses in Rio de Janeiro related to food. Ideas are not lacking in Raphael's creative head. 


\section{REFERENCES}

Danjou, I. L' (2002). L'entrepreneuriat: Un champ fertile à la recherche de son unité. Revue Française de Gestion, 28(138), 109-125. Retrieved from https://www. econbiz.de/Record/l-entrepreneuriat-un-champ-fertile$\%$ C3\%A0-la-recherche-de-son-unit \%C3\%A9-danjouisabelle/ 10001723646

Gaulejac, V. de. (2005). História e historicidade. In V. de Gaulejac; S. R. Marquez \& E. T. Ruiz (Orgs.), História de vida: Psicoanálisis y sociología clinica (pp. 61-90). México: Edición de la Universidad Autónoma de Querétaro.

Guimarães, E. H., Jr, (2019). Como os empreendedores trabalham: Uma leitura psicodinâmica da organização do trabalho de um grupo de empreendedores. Revista de Empreendedorismo e Gestão de Pequenas Empresas, 8(1), 149-175. Retrieved from https://www.regepe.org.br/regepe/article/view/889/pdf

Legrand, M. (1993). Le récit de vie. In M. Legrand. L'approche biographique (pp. 178-241). Marseille: Hommes et Perspectives.

\section{Authorship}

\section{Valéria Quiroga Vinhas}

Universidade Federal do Rio de Janeiro, Instituto COPPEAD de Administração

Rua Pascoal Lemme, no 355, Cidade Universitária, 21941-918, Rio de Janeiro, RJ, Brazil.

E-mail address: vqv@hotmail.com

(D) https://orcid.org/0000-0002-8591-0825

\section{Ana Luiza Szuchmacher Verissimo Lopes*}

Universidade Federal do Estado do Rio de Janeiro, Departamento de Estratégia de Gestão

Rua Voluntários da Pátria, no 107, Botafogo, 22270-000, Rio de Janeiro, RJ, Brazil.

E-mail address: ana.lopes@unirio.br

(D) https://orcid.org/0000-0001-7439-4979

* Corresponding Author

\section{Funding}

The authors reported that there is no financial support for the research in this article.

\section{Conflict of Interests}

The authors have stated that there is no conflict of interest.

\section{Copyrights}

RAC owns the copyright to this content.
Paiva,F.G.,Jr,Almeida,S.L., \& Guerra,J.R.F.(2008).Oempreendedor humanizado como uma alternativa ao empresário bemsucedido: um novo conceito em empreendedorismo, inspirado no filme Beleza Americana. RAM. Revista de Administração Mackenzie, 9(8), 112-134. Retrieved from http://www.redalyc.org/pdf/1954/195416658007.pdf

Schön, D. A. (1995). The reflective practitioner: How professionals think in action. Aldershot, UK: Arena.

Shane, S., \& Venkataraman, S. (2000). The Promise of Entrepreneurship as a Field of Research. The Academy of Management Review, 25(1), 217-226. https://doi.org/10.2307/259271

Shook, C. L., Priem, R. L., \& McGee, J. E. (2003). Venture creation and the enterprising individual: $\mathrm{A}$ review and synthesis. Journal of management, 29(3), 379-399. https://doi.org/10.1016/S0149-2063(03)00016-3

\section{Authors' Contributions}

$\mathbf{1}^{\text {st }}$ author: conceptualization (equal); data curation (equal); formal analysis (equal); investigation (equal); methodology (equal); project administration (equal); writing-original draft (equal); writing-review \& editing (equal).

$2^{\text {nd }}$ author: conceptualization (equal); data curation (equal); formal analysis (equal); investigation (equal); methodology (equal); project administration (equal); writing-original draft (equal); writing-review \& editing (equal).

\section{Plagiarism Check}

The RAC maintains the practice of submitting all documents approved for publication to the plagiarism check, using specific tools, e.g.: iThenticate.

\section{Peer Review Method}

This content was evaluated using the double-blind peer review process. The disclosure of the reviewers' information on the first page, as well as the Peer Review Report, is made only after concluding the evaluation process, and with the voluntary consent of the respective reviewers and authors.

\section{Data Availability}

RAC encourages data sharing but, in compliance with ethical principles, it does not demand the disclosure of any means of identifying research subjects, preserving the privacy of research subjects. The practice of open data is to enable the reproducibility of results, and to ensure the unrestricted transparency of the results of the published research, without requiring the identity of research subjects. 